\title{
Modeling and Control of an Offshore Wind Farm connected to Main Grid with High Voltage Direct Current Transmission
}

\author{
Ahmet Mete Vural (D, Auwalu İbrahim İsmail \\ Department of Electrical and Electronics Engineering, University of Gaziantep, Gaziantep, Turkey
}

Cite this article as: A. M. Vural A. I. İsmail, ,"Modeling and Control of an Offshore Wind Farm Connected to Main Grid with High Voltage Direct Current Transmission", Electrica, vol. 18, no: 2, pp. 198-209, 2018.

\begin{abstract}
Offshore wind farms inherently need alternating current (AC) grid connection with undersea cables. However, this requires reactive power compensation, which is costly and not practical. Moreover, it threads the stability of the system. For these reasons, high voltage direct current (HVDC) transmission is a promising solution since no reactive power is needed. Furthermore, the DC power flow between offshore and onshore locations as well as the reactive power at either side can easily be controlled by voltage source converters (VSCs). In this paper, the modeling and control of an offshore wind farm connected to the mainland grid power with HVDC transmission is proposed. A control strategy is proposed to control active and reactive power at the offshore wind farm converter and DC voltage at the onshore converter. The overall system, including wind farm, offshore and onshore converters, HVDC transmission, and AC grid side, were tested and verified in a simulation environment. The designed control systems of the VSCs were tested by various case studies.
\end{abstract}

Keywords: Offshore wind farm, doubly fed induction generator, high voltage direct current, undersea DC cable

\section{Corresponding Author: \\ Mete Vural}

E-mail:

mete.vural@gaziantep.edu.tr

Received: 03.01.2018

Accepted: 30.05 .2018

(c) Copyright 2018 by Electrica

Available online at

http://electrica.istanbul.edu.tr

DOI: 10.26650/electrica.2018.73966

\section{Introduction}

Renewable energy as a natural source of power for people offers infinite opportunities as well as challenges to power system architecture. One of the many benefits derived from renewable energy sources is that free energy is available and that it can be exploited in its natural form, thereby providing economical sources of energy [1]. Conventional energy sources like coal, nuclear or natural gas can contaminate the environment, whereas fuel cell, wind, geothermal and solar energy - all being renewable sources - are fresh and richly available in nature. Among these renewable energy sources, wind energy is the best option because of the large wind energy potential, especially in European countries. In 2008 alone, about $27 \mathrm{GW}$ of wind power was installed worldwide, which amounted to around $120.8 \mathrm{GW}$ of the total installed capacity [2].

Wind energy industries experienced a strong growth a few years ago, which has led to great improvements in offshore application [3]. This development is set to be a huge step forward for Europe's power system planning. Offshore wind farms have been a growing trend compared to onshore wind farms because of the unavailability of onshore sites and wind is more powerful and persistent on offshore sites. $1100 \mathrm{MW}$ of power was developed for 25 projects in five European countries in the year 2007 all of which were big and completely marketed projects $[3,4]$. Wind farm exploitation requires an installation of a number of wind turbines located at a distance from the shoreline in excess of hundred of kilometers. The installation mostly employs doubly fed induction generators (DFIGs), which involves decouple control of back-to-back (BTB) converters so as to permit adjustable speed operation of the turbine and a cost effectiveness.

High voltage direct current transmission has become a feasible solution economically and technologically for connecting an offshore wind farm and its load over a long distance taking into 
account an increase in demand for the capacity of the offshore wind farms [5]. Generally an offshore wind farm is located far away from an onshore grid point of common coupling (PCC) which makes the HVDC use VSC as a preferable solution [6]. HVDC transmission is a more suitable solution for connecting the two converter stations due to the weakness of the connection as a result of long distance transmission. HVDC transmission using VSCs was first launched in Sweden in 1997 which was rated at 3 MW as a trail [7]. It covered a distance of $10 \mathrm{~km}$. During that year the project went into operation to demonstrate the feasibility of the technology to operate in a network. The $50 \mathrm{MW}$ Gotland HVDC light project covering a distance of $70 \mathrm{~km}$, transports wind power from southern Gotland to the center of the island. It has been in operation since November 1999 [8]. Directlink is a 180 MVA HVDC light project that connects the regional electricity markets of new South Wales and Queensland [9].

In current years, one of the fastest growing renewable-energy resources is wind energy which has many benefits such as being clean and sustainable [10]. Offshore locations are very suitable for wind energy production by for following reasons: 1) in most countries, the best onshore locations for wind energy production are already occupied or soon to become new wind farm locations, 2) higher wind speeds (up to $20 \%$ greater) are available above the sea when compared to land location, as a result more power (up to 70\%) can be extracted from wind, 3 ) the absence of obstacles such as hills and the smooth surface of the sea make wind energy more reliable when compared to a land location. An offshore wind farm inherently needs AC grid connection with undersea cables. However AC transmission of electrical power with these cables requires a high amount of reactive power which is impractical, expensive, and difficult to control for stable operation [1]. Due to these limitations, the HVDC transmission option is ideal for undersea power transfer between the offshore wind farm and the onshore power substation. Many projects of this type exist such as the BorWin [10] and DolWin [11] projects in Europe. HVDC power transmission inherently requires no reactive power and it is reliable. Moreover DC power flow can easily be controlled by means of VSCs located both offshore and onshore, between the two ends of the undersea cable. Another advantage of the HVDC power transmission option is that it can be connected to weak radial systems [12]. In order to fully benefit an offshore wind farm connected with HVDC, the control system of the VSCs should be designed so as to satisfy reliable operation with high sustainability and efficiency of energy [13].

Turkey does not have an offshore wind farm installation yet. So this is our main motivation. This study suggests a simulation model for an offshore wind farm connected to the main AC grid with HVDC transmission under the sea as shown in Figure 1. The overall control system of the VSCs of HVDC transmission was studied and verified in this work. This paper is organized as follows: Section 2 gives a general overview of the components of an offshore wind farm. Section 3 discusses HVDC transmission connecting an offshore wind farm to the grid. Section 4



proposes the control strategy for HVDC VSCs. The simulation study is explained in Section 5. Finally, Section 6 draws a conclusion.

\section{Understanding Offshore Wind Farm with High Voltage Direct Current}

\section{Wind Turbine Overview}

Generally there are two types of wind turbine generators: Constant speed wind turbine generators and fixed speed wind turbine generators. The performance and construction of constant-speed wind turbines depends solely on mechanical sub-circuit features such as pitch-control, time constant and maximum switching rate of the main circuit breaker. Today's high power wind turbines are generally capable of variable speed operation [15].

\section{Type of Adjustable Speed Generators (ASG)}

The most common type of ASG is the direct-in-line system [15]. In this scheme, a synchronous generator generates variable frequency $A C$ power. This power is transformed using power converters connected in series with an ASG into fixed-frequency AC power.

As wind power industries rapidly increase, three types of wind turbine generators are widely used for offshore application. Based on their operational speed, these generators are differentiated into three categories, namely fixed, limited and variable speed. The generators are:

\section{Squirrel Cage Induction Generator (SCIG)}

Frequency regulation of local generator grid side makes the SCIG the simplest choice for offshore generators in order to 
achieve power for the turbines. This advantage of SCIG makes it simpler to use when choosing generators for offshore wind farm application. It should be noted that effective cost and losses in generators are much higher for structures with separate converter arrangements than those with a common single converter arrangement. Also wind speed variation for wind turbines can affect their operating condition irrespective of the common frequency of the generators. Maximum power point tracking (MPPT) cannot be possible when the turbine generators are connected separately [14].

\section{Permanent Magnet Synchronous Generator (PMSG)}

In this type of generator arrangement, an AC/DC/AC converter connected to BTB is used to convert the generator output power to a nominal frequency of local grid, which is later conveyed to an offshore rectifier station. PMSGs do not have gearboxes and have multiple poles, which makes them efficient and reliable. However they are expensive.

\section{Doubly Fed Induction Generator (DFIG)}

This is the most common turbine generator system used in offshore wind farms [14]. These generators are capable of variable speed operation and have lower cost and losses compared to other variable speed turbine generators. One drawback of DFIG over PMSG is its limited speed variation range, but this can be overcome by regulating the generator side local frequency thereby increasing the range of its allowed speed variation.

In this paper, a DFIG is considered, where the rotor winding is fed through BTB variable frequency VSC [14]. The configuration of DFIG is schematically shown in Figure 2.

\section{Understanding the VSC-HVDC System}

For short distance cable transmission of power, high voltage $A C$ is a suitable solution because it is cheaper since it needs no



Figure 2. DFIG wind turbine basic configuration [16] converters or filters. But when cable transmission exceeds 70 $\mathrm{km}$, HVDC becomes more economical because it reduces the use of bulk transmission cables and does not require reactive power compensation equipment like STATCOM in order to deliver real energy to the land over such a long distance [17].

HVDC based VSC technology is a promising solution for transmitting bulk power from an offshore location to the onshore AC main grid [18]. It uses power electronic converters that employ insulated gate bipolar transistors (IGBT), aiming at decoupling control of active and reactive power. It allows the connection of two or more AC systems that are operating at different frequencies. It also permits connection to a weak AC system network.

VSC based HVDC transmission represents an important improvement over classical HVDC [19],[20]. It is broadly divided into two categories, based on the operating principle:

1. Line commutated converters that need AC system for their operation. AC voltage can force the current to commutate from one phase to another.

2. Self commutated converters that do not need AC system for their operation. They are further divided into VSC and current source converters (CSC). In CSC, the reactors provide smooth DC current for proper operation. In VSC, the storage capacitor provides a smooth DC voltage for proper operation.

The VSC, which is a self-commutated converter, has emerged as a solution to classical converters because of the advantages mentioned below:

- Fast and independent active and reactive power control

- Black start capability

- Capacity of variable frequency operation

- Allowance of multiterminal network structure

- Constant improvement of control quality instabilities

\section{Converter Topology}

Converter topologies are divided based on their circuit topology and the number of voltage levels at output [21].

\section{Two-level VSC topology}

This is the simplest form of VSC configuration, which generates two-voltage level. It consists of 6 IGBTs and 6 anti-parallel connected diodes at each IGBT. It uses pulse width modulation to control its AC output waveform.

\section{Three-level VSC topology}

This comprises 4 valves in one phase leg. The switching rule is that any two valves that are directly connected in the series cannot be switched at the same time.

\section{Modular Multilevel Converter}

Modular multilevel converter is suitable for high or medium-voltage power conversion because of its simpler construc- 
tion and flexibility in converter design. It is based on cascaded connection of multiple bi-directional chopper-cells per leg, thus requiring voltage-balancing control of the multiple floating DC capacitors.

\section{Design and Control of Offshore Wind Farms}

The mechanical power of aerodynamic model that can be obtained after wind blows is given as

$$
P_{w}=\frac{1}{2} r \mathrm{p} R^{2} v^{2} C_{p}(\mathrm{q}, \mathrm{I})
$$

where, $P_{w}$ is the wind power in watt, $\rho$ is the density of air in $\left(\mathrm{kg} / \mathrm{m}^{3}\right), v$ is the wind speed in $(\mathrm{m} / \mathrm{s}), C_{p}$ is the power coefficient which is a function of the pitch angle of rotor blades $\theta$ (deg), $R$ is the radius of the blade in ( $m)$, and $\lambda$ is the tip speed ratio, given as

$$
\lambda=\omega_{w} R / v
$$

where $\omega_{w}$ is the wind turbine speed.

$$
\begin{aligned}
C_{p} & =0.73\left(\frac{151}{\lambda_{i}}-0.58 \theta-0.002 \theta^{2.14}-13.2\right) \cdot e^{-18.4 / \lambda_{i}} \\
\frac{1}{\lambda_{i}} & =\frac{1}{\lambda-0.02 \theta}-\frac{0.003}{\theta^{3}+1}
\end{aligned}
$$

Eqns (1-4) can be used to derive the power curves for different wind speeds. The wind turbine control is to allow the ideal power factor to capture optimum power in case of low to moderate speeds. But in higher wind speeds, the pitch angle controller performs the function of preventing the rotor speed being very extreme. A turbine speed at any given wind velocity obtains the optimal output power [22],[23].

\section{Drive train model}

A two-mass drive train model is suitable for a comparative study of wind turbine systems for different models of drive train[11]. Drive train model is described as

$$
\begin{gathered}
J_{w} \frac{d \omega_{w}}{d t}=T_{w}-K \theta_{w g}-D\left(\omega_{w}-\omega_{g}\right) \\
J_{g} \frac{d \omega_{g}}{d t}=K \theta_{w g}-D\left(\omega_{w}-\omega_{g}\right)-T_{g}
\end{gathered}
$$

where,

$T_{w}$ is wind turbine aerodynamic torque ( $\mathrm{N} \mathrm{m}$ )
$T_{g}$ is the loading torque of the generator

$J_{w}$ represent wind turbine inertia constant

$J_{g}$ is generator inertia constant

$\theta_{w g}$ is the angle between generator and turbine rotor (deg)

$\omega_{w}$ is wind turbine speed $(\mathrm{m} / \mathrm{s})$

$\omega_{g}$ is generator rotor speed $(\mathrm{rad} / \mathrm{s})$

$D$ is the mutual damping between two masses ( $\mathrm{N} \mathrm{ms} / \mathrm{rad}$ )

$K$ is the elastic characteristics of the shaft $(\mathrm{N} \mathrm{m} / \mathrm{rad})$

\section{Modeling of DFIG}

The DFIG employs a wound rotor induction generator, where the rotor winding is fed via BTB variable frequency VSCs [24]. An over-current 'crowbar' circuit and a voltage limiter are employed to protect the machine and converters. Decoupled control of power system electrical frequency and rotor mechanical frequency are achieved through the converter system providing the variable speed operation of wind turbines. It consists of two VSCs. A rotor side converter (RSC) that is used to generate three-phase voltage with variable amplitude and frequency achieves the control of generator torque, the exchange of power between the stator and the grid. The grid side converter (GSC) acts to exchange active power extracted by the RSC to the grid. Capacitors are placed between the converters for maintaining DC link voltage [25].

\section{Grid Side Converter (GSC)}

This converter is a three-phase one consisting of double-pole VSC employing six IGBT switches. GSC allows bi-directional power flow. It is a force-commutated converter with pulse width modulation (PWM). The current control method is also used for GSC. The current drawn by the converter from the grid is kept constant. Capacitors are placed between the converters for maintaining dc-link voltage. A current control strategy is employed as GSC control. It comprises two control loops, the inner current loop and the outer current loop shown in Figure 3. The inner current loop ensures grid reactive power and the outer current loop keeps the DC voltage to a continuous value. The real value of the $D C$ link voltage is compared with the reference DC voltage [26].

PI processes the error signal. PI controller output is compared to the actual current element of the VSC. Also, grid reactive power and reactive current element of the inverter are compared and their error values are computed using this controller [27]. Reference values of $d-q$ and $a b c$ frames are converted using voltage input reference. Then the modulation index is computed at the 




Figure 3. GSC control structure [14]

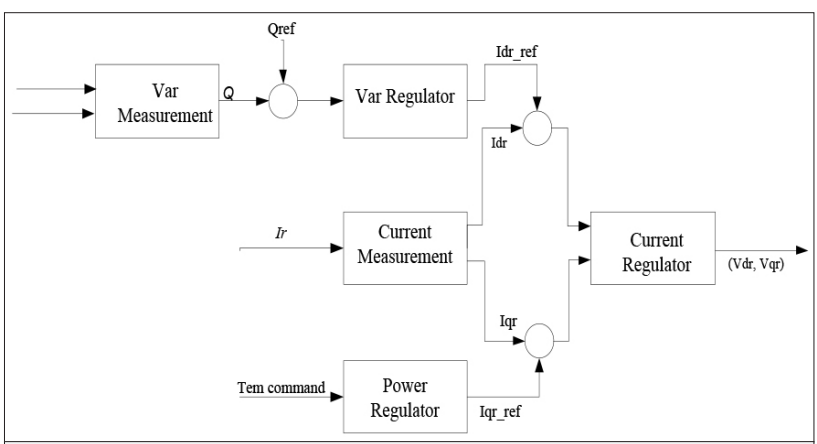

Figure 4. RSC control structure [14]

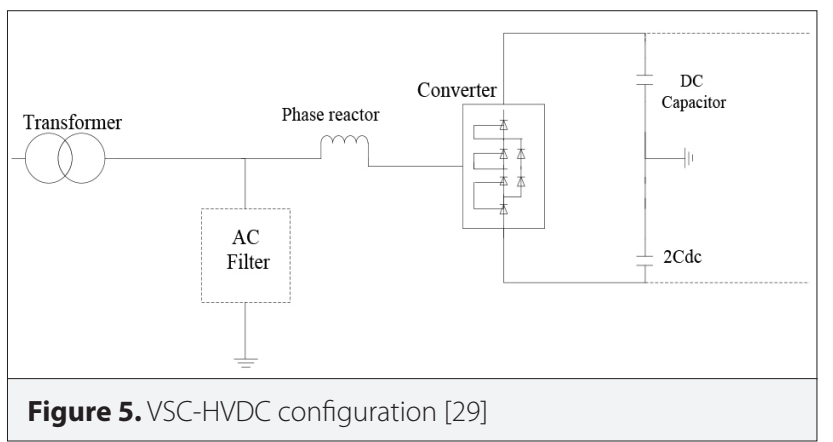

PI controller output. The converter AC terminals and the machine stator are linked via the transformer. Space vector pulse width modulation (SVPWM) receives its reference signal from the PI controller to produce pulses to the GSC controls.

The control of power in the stator is achieved by the RSC. Reference signal is generated to control stator power, which depends on the power reference. Vector control technique is used for RSC control [28]. Field-oriented control (FOC) is used for RSC control, which is later modified to direct power control (DPC). The DPC is based on direct control of active and reactive power of the DFIG stator that is determined by the following current and voltage equations:

$$
P_{s}=\frac{3}{2} R_{e}\left(V_{s} \cdot I_{s}\right)
$$

$Q_{s}=\frac{3}{2} I_{m}\left(V_{s} \cdot I_{s}\right)$

where

$P_{s}$ and $Q_{s}$ are the stator real and reactive power,

$V_{s}$ and $I_{s}$ are the voltage and current components of stator.

Using $d$ - $q$ transformation of voltage and current, stator active and reactive power are calculated thus:

$P_{s}=\frac{3}{2}\left(v_{d s} \cdot i_{d s}+v_{q s} \cdot i_{q s}\right)$

$Q_{s}=\frac{3}{2}\left(v_{q s} \cdot i_{d s}+v_{d s} \cdot i_{q s}\right)$

$v_{d s}, v_{q s}$ and $i_{d s}, i_{q s}$ are respectively the stator voltages and currents component in $d$ - $q$ reference frame.

Active and reactive power of the stator from equations (7) and (8) are compared by their reference values and the error is processed with the PI controller to generate a $d q$ component of grid voltage reference. This grid voltage reference is then transformed to $a b c$ reference frame which gives a three phase voltage reference to the SVPWM system of the RSC. The structure of RSC is shown in Figure 4.

\section{Modeling and Control System of VSC-HVDC}

A three level VSC with SVPWM is considered in this work. The VSC configuration is an arrangement of single IGBTs and diodes components connected in parallel. The configuration is illustrated in Figure 5.

The VSC design specification is the same for both the wind farm and the GSC. Furthermore, the control scheme for these converters depends on the requirement for control objectives at hand. Transformers are connected between AC system and converters. It is used to upgrade the AC voltage to a level appropriate to the converter. AC filters are employed to remove the voltage harmonics injected into the AC system. They are arranged as connected in shunt high pass filter arranged in the order of PWM frequency. Reactors are used to control active and reactive power by controlling currents through them, then minimizing the frequency harmonic parts for primary line-current of the converter that is caused by the switching of the VSCs. When modeling the DC cable, shunt capacitance and resistance are ignored. Only the series resistance is modeled as lumped resistive element. Series inductance is also ignored. 
In VSC-HVDC, PWM gives the harmonic current that causes ripples on the DC side voltage. Shunt connected capacitors are used to filter out the ripples and give a smooth DC voltage. The time constant is the ratio of capacitor storage energy at rated $D C$ voltage and the rated apparent power.

Mathematically, it can be shown as

$$
\tau=\frac{c u_{D C}^{2}}{2 S_{n}}
$$

where

$c$ is the DC capacitance in $\mu F$

$u_{D C}$ is the $\mathrm{DC}$ voltage in $\mathrm{KV}$

$S_{n}$ is the rated power in MVA

The above formula can be used to determine the value of the DC capacitor [29].

\section{Control Strategy}

The VSC based HVDC control is established by two controllers: the outer controller and the inner current controller [30],[31] as depicted in Figure 6. The inner current controller is used to control AC current while the outer controllers supply its reference values. The outer controllers are: Active power controller, Reactive power controller and DC voltage controller. The active power and DC voltage controllers provide reference values of active current while $\mathrm{AC}$ voltage and reactive power controllers provide reference values of reactive current. Steady state errors for these controllers are removed using integrators. In this



Figure 6. Control system of VSC-HVDC converter strategy, one converter controls the DC voltage to attain power stability. The other converter can be set at a value of any active power within the limit for the system [32].

\section{Simulation Studies}

This section is based on simulation studies of the performance of an offshore wind farm connected to VSC based HVDC for the control of wind turbine generator, offshore converter, onshore converter, and to ensure quality output of power to the grid from the offshore wind farm. The simulation software was used for designing and simulation of the model. In the study, converter-level models in which the converters are modeled in the semiconductor switching-level were used. This enables more realistic results for dynamic performance analysis when compared with phasor models in which the switching of the power semiconductors are fully ignored and each VSC is modeled as an AC voltage source with controllable magnitude and controllable phase angle. Initially, the wind turbine generator controller was designed to control the generator speed at a certain wind speed (in this work $15 \mathrm{~m} / \mathrm{s}$ wind speed was selected to test the performance of controllers) and ensure that a high quality of power was delivered to the grid. This power is then transmitted to the GSC that controls the DC voltage. The converter is a three-phase one consisting of double pole VSI employing 6-IGBT switches. It allows bi-directional power flow. A DC link voltage should be constant when the converter draws current from the grid and as a reference to keep DC link voltage. Capacitors values are chosen appropriately to maintain constant DC-link voltage.

\section{Test System under Study}

As described in previous sections, the offshore wind farm contains a number of wind turbines coupled together to transmit power to the grid and to achieve MPPT. The effect of the DFIG based offshore wind farm will be analyzed in order to achieve reliable and stable power transmits to the grid when connected through VSC-HVDC link. The test system consists of 60 wind turbines; each is rated at 1.5 MW. Each of them is connected to the offshore converter (rectifier) through an individual step-up transformer. The generator rated capacity is chosen to be 1.5 MW, and its parameters are shown in Table 1.

The HVDC link parameters are given in Table 2. Control parameters for HVDC converters (offshore and onshore) are given in Table 3, 4 respectively. The strategy implemented is the direct power control of wind turbine generator where the converter is designed to control active and reactive power of the stator for DFIG. Control parameters of DFIG are given in Table 5. The simulation period is selected as $3 \mathrm{sec}$.

\section{HVDC Submarine Cable Selection}

In this study, $\pm 100 \mathrm{KV}$ submarine polymer cables are used. This cable differs from the conventional thyristor-based HVDC cable 
Table 1. DFIG Parameters

\begin{tabular}{lc}
\hline Parameter & Rating \\
\hline Power rated & $1.5 \mathrm{MW}$ \\
\hline Base voltage & $575 \mathrm{~V}$ \\
\hline Base frequency & $50 \mathrm{~Hz}$ \\
\hline Base impedence on stator & 0.2381 \\
\hline Base stator current & $2.37 \mathrm{kA}$ \\
\hline Base speed & $1400 \mathrm{r} / \mathrm{min}$ \\
\hline Torque & $11.9 \mathrm{kNm}$ \\
\hline Rotor voltage & $690 \mathrm{~V}$ \\
\hline Rotor current & $1.5 \mathrm{kA}$ \\
\hline
\end{tabular}

Table 2. HVDC transmission Parameters

\begin{tabular}{|c|c|c|}
\hline Parameter & Rating & $\begin{array}{l}\text { Per unit } \\
\text { value }\end{array}$ \\
\hline Base generated power & $90 \mathrm{MW}$ & 1.0 \\
\hline Base DC voltage & $100 \mathrm{KV}$ & 1.0 \\
\hline Converter transformer rating & $200 \mathrm{MVA}$ & - \\
\hline $\begin{array}{l}\text { Simple AC system at offshore } \\
\text { station }\end{array}$ & $230 \mathrm{KV} / 50 \mathrm{~Hz}$ & 1.0 \\
\hline Offshore side transformer ratio & $25 \mathrm{KV} / 230 \mathrm{KV} / 100 \mathrm{KV}$ & - \\
\hline DC transmission line & $2 * 75 \mathrm{~km}$ Pi section & - \\
\hline $\begin{array}{l}\text { DC line Inductance per } \\
\text { kilometer }\end{array}$ & $0.156 \mathrm{H} / \mathrm{km}$ & - \\
\hline $\begin{array}{l}\text { DC line resistance per } \\
\text { kilometer }\end{array}$ & $0.517 / \mathrm{km}$ & - \\
\hline $\begin{array}{l}\text { DC line capacitance per } \\
\text { kilometer }\end{array}$ & $2.85 \mathrm{~F} / \mathrm{km}$ & - \\
\hline Phase reactor inductance & $0.024 \mathrm{H}$ & 0.15 \\
\hline Phase reactor resistance & $0.075 \Omega$ & 0.015 \\
\hline \multirow{2}{*}{$\begin{array}{l}\text { Onshore side transformer } \\
\text { rating }\end{array}$} & $100 \mathrm{KV} / 230 \mathrm{KV}$ & \\
\hline & 200MVA & - \\
\hline AC filter & $\begin{array}{l}40 \mathrm{MVar} \text { at } 27^{\text {th }} \text { and } \\
54^{\text {th }} \text { harmonics }\end{array}$ & - \\
\hline AC Grid system & $230 \mathrm{kV} / 50 \mathrm{~Hz}$ & 1.0 \\
\hline
\end{tabular}

which uses self-contained oil filled or mass impregnated paper insulated cable. Power reversal is achieved by changing the direction of the current flow.
Table 3. Control parameter for offshore converter

\begin{tabular}{lccc}
\hline Controllers & Ki & Kp & Kf \\
\hline P regulator & 20 & - & - \\
\hline P control & 3.0 & 3.0 & - \\
\hline Q regulator & 20 & - & \\
\hline Inner current regulator & 0.6 & 6.0 & 0.3 \\
\hline
\end{tabular}

Table 4. Control parameter for onshore converter

\begin{tabular}{lccc}
\hline Controllers & Ki & Kp & Kf \\
\hline DC voltage regulator & 40 & 20 & - \\
\hline Q regulator & 20 & - & - \\
\hline Q control & 3.0 & 3.0 & - \\
\hline Inner current regulator & 6.0 & 0.6 & 0.3 \\
\hline DC voltage balance control & 0.03 & 0.2 & - \\
\hline
\end{tabular}

Table 5. DFIG control parameters

\begin{tabular}{lcc}
\hline Parameter gain & Kp & Ki \\
\hline GSC current regulator gains & 0.83 & 5 \\
\hline DC voltage regulator gains & 8 & 400 \\
\hline Speed regulator gains & 3 & 0.6 \\
\hline RSC current regulators gains & 0.6 & 8 \\
\hline Q and V regulator gains & 0.05 Var & 20 volt \\
\hline Pitch controller gain & 150 & - \\
\hline Pitch compensation gains & 3 & 30 \\
\hline
\end{tabular}

\section{Dynamic Performance of the System}

\section{Case 1: Steady State Performance}

The active and reactive power generated by the wind farm for a nominal wind speed of $11 \mathrm{~m} / \mathrm{s}$ is shown in Figure 7. As the wind speed is increased from 11 to $15 \mathrm{~m} / \mathrm{s}$, the generator speed and air gap torque both increase while the stator flux link remains constant. Also generator active power and reactive power tend to increase because of the constraints arising from changes in the system voltage and frequency. This is a result of the control effort of the HVDC rectifier since it limits and also stabilizes the changes in measured value of system frequency at the rectifier end.

In Figure 7, nominal DC voltage of the DFIG is set as $1150 \mathrm{~V}$ and the output is shown with some ripples at the start up which is caused by charging and discharging of capacitors. 




(a)



(b)

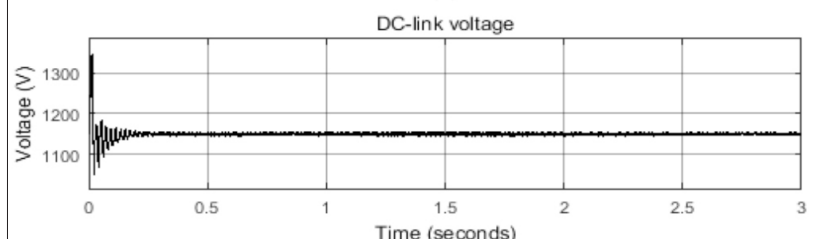

(c)

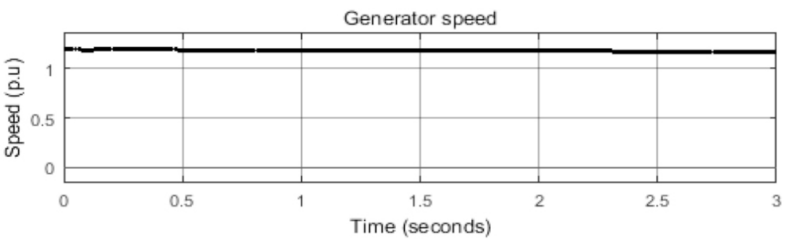

(d)

Figure 7. a-d. Waveforms for generator at nominal wind speed to (a) active power (b) reactive power (c) DC link voltage (d) generator speed.

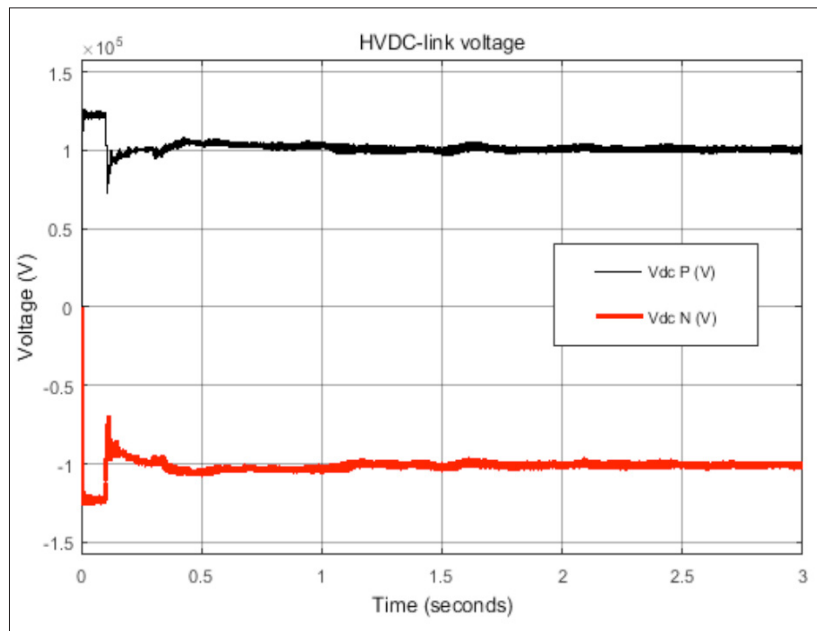

Figure 8. HVDC link voltage

It is observed that the voltage reaches its steady-state value at approximately 0.3 seconds. The DC link voltage at HVDC side is shown in Figure 8. The nominal voltage is set at $1 \mathrm{p.u}$ (100KV)

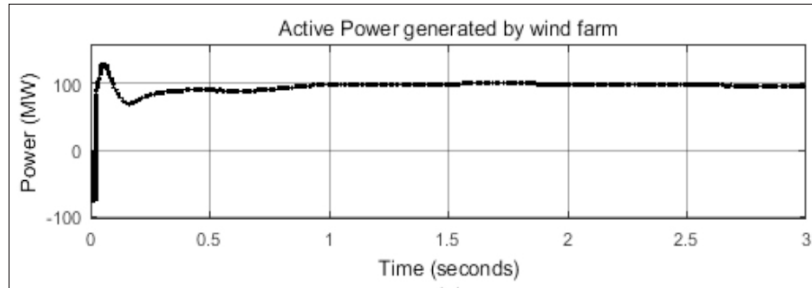

(a)

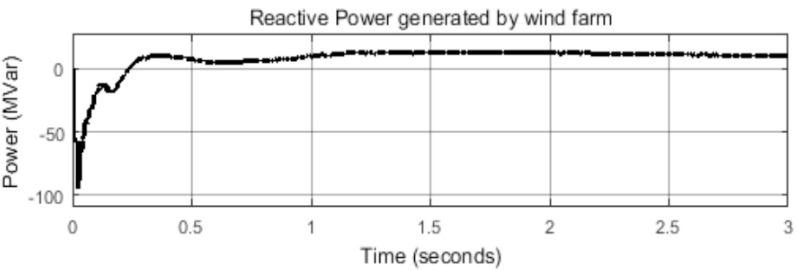

(b)

Figure 9. Response to change in wind speed to (a) active power (b) reactive power

\section{Case 2: Response to change in wind speed}

Initially, wind speed was predetermined at $11 \mathrm{~m} / \mathrm{s}$ and it rapidly increased to $15 \mathrm{~m} / \mathrm{s}$. Also in this time interval, the active power generated tended to rise smoothly until at $1 \mathrm{sec}$ it reached its rated value as shown in Figure 9.

\section{Step changes to HVDC Controllers}

In the following case studies, the design of controllers involves two strategies:

1. Offshore converter controller is designed to control active power $(\mathrm{P})$ and reactive power $(\mathrm{Q})$

2. Onshore converter controller is designed to control reactive power $(\mathrm{Q})$ and $\mathrm{DC}$ voltage $\left(\mathrm{V}_{d c}\right)$.

\section{Case 3: Step change to active power controller}

The wind farm VSC controller reference is set to $1 p . u$. At 0.3 s the power is ramped up slowly to reach its set value of active power reference ( $90 \mathrm{MW}$ at 0.9 power factor) at $1.0 \mathrm{sec}$. Also at 1.5 $\mathrm{sec}$, a $-0.1 \mathrm{p}$.u step is applied to the active controller reference and response is observed. Figure 10 shows that the controller can respond to any change in the system. Subsequently the measured active power follows its reference active power at any instant in the simulation process. Similarly, an active power reference (Pref) is set to $0.5 \mathrm{p} . \mathrm{u}$ and at $1.5 \mathrm{sec}$, a step change of $0.1 \mathrm{p} . \mathrm{u}$ is applied to the controller reference and the response is observed.

\section{Case 4: Step change to reactive power controller}

A step change of $0.1 p . u$ is applied at $1.5 \mathrm{sec}$ for reactive reference power and the response from Figure 11 shows that the measured reactive power follows its reference power at any 


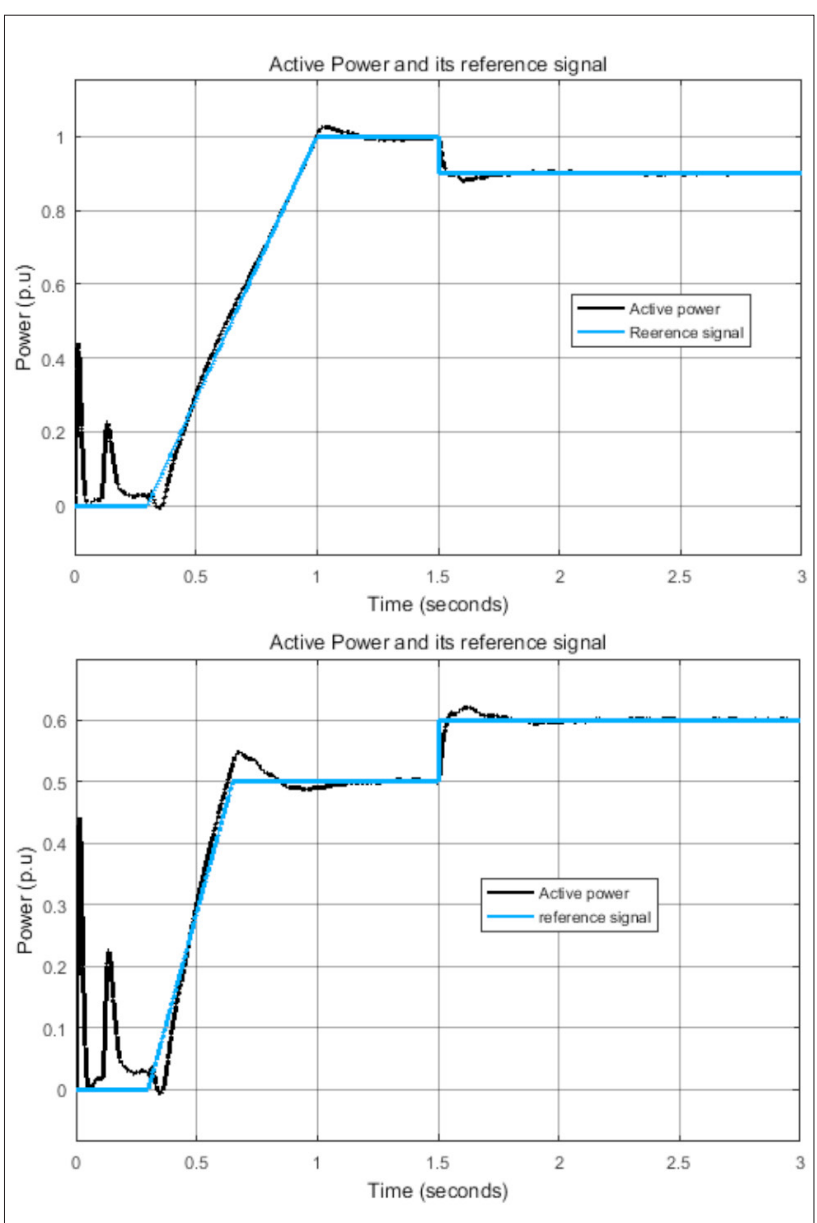

Figure 10. Response to step changes in active power at HVDC rectifier station (increase and decrease)

instant. Also step change to the decrease in reactive power at $1.5 \mathrm{sec}$ is also observed. The reactive power can be controlled to a null value in an offshore converter station since it is a common control at both converter stations.

\section{Case 5: Step change to DC voltage controller}

The GSC controller is established to control reactive power and ensures constant DC voltage at the HVDC side. The DC voltage reference is set to 1 p.u. Steady state is reached at about $0.15 \mathrm{sec}$. The controller performance to the change in DC voltage is observed and it showed that there is a decrease in voltage to about $0.05 \mathrm{p} . \mathrm{u}(5 \mathrm{KV}$ ) at $1.5 \mathrm{sec}$ because of the step change in the DC reference voltage from 1 p.u to 0.95 p.u as shown in Figure 12.

\section{Fault Analysis}

\section{Case 6: Voltage sag at Offshore side of the Wind Farm}

A three-phase programmable voltage source is employed at the offshore side of the wind farm and voltage sag is applied at
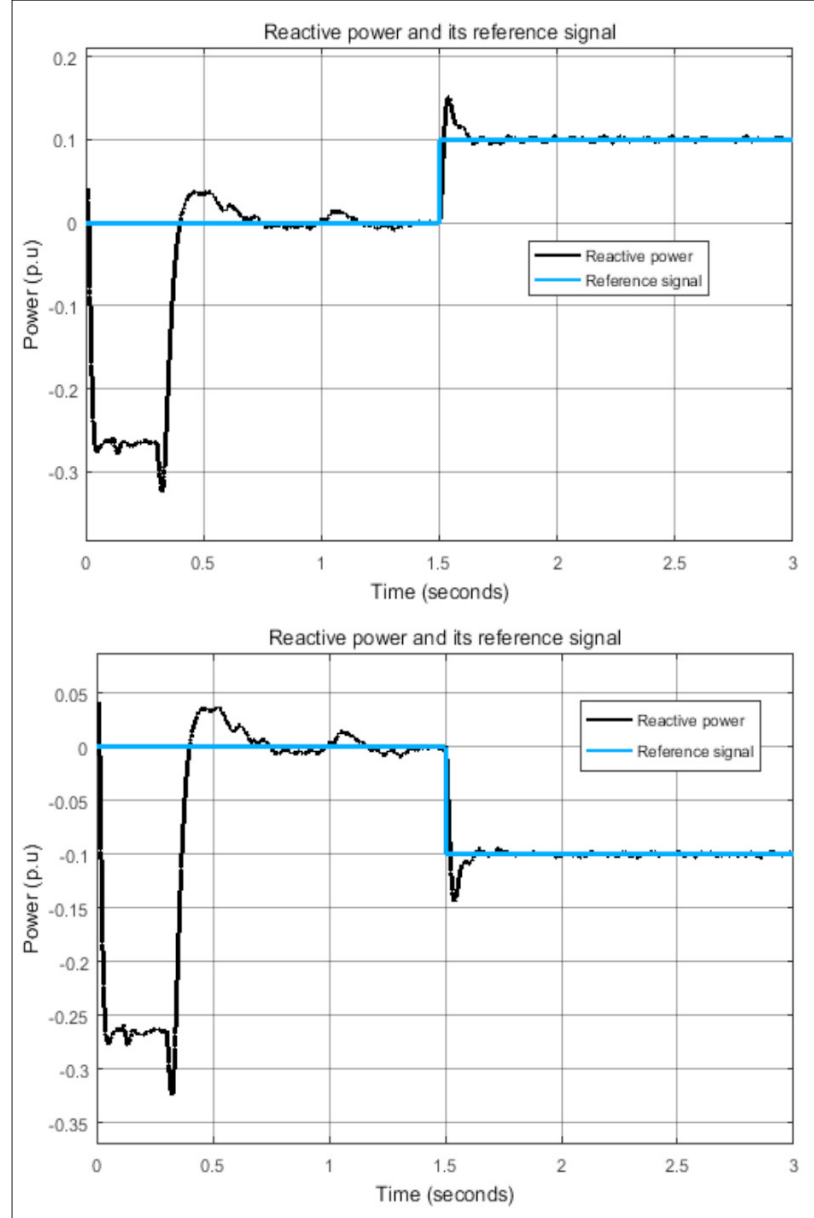

Figure 11. Response to step changes in reactive power at HVDC rectifier station (increase and decrease)

$1.5 \mathrm{~s}$. As a result, the active power delivered from the wind farm tends to deviate from the pre-disturbance state by 0.2 p.u and reactive power also by $0.2 \mathrm{p}$.u. The system returns back to its normal operation after $0.14 \mathrm{~s}$ from the perturbation as shown in Figure 13. The simulation time is $3 \mathrm{sec}$. Response to HVDC controllers at HVDC link under this fault is shown in Figure 14. Also response to fault at the wind farm side for active and reactive power is shown in Figure 15.

\section{Case 7: Three-Phase to Ground Fault at the Onshore AC Main Grid}

A three phase to ground fault is applied at the grid side of the wind farm and at 1.5s, the DC power delivered by the wind farm almost ceased DC voltage rose to 1.2p.u as shown in Figure 16 due to excessive charging of the DC capacitors. The recovery time from perturbation is $0.12 \mathrm{~s}$ as shown from the simulation diagrams in Figure 17. DC voltage control override, which is a function in the active power controller, limits the DC voltage to a specified range. Wind farm active and reactive power under this fault is shown in Figure 18. 


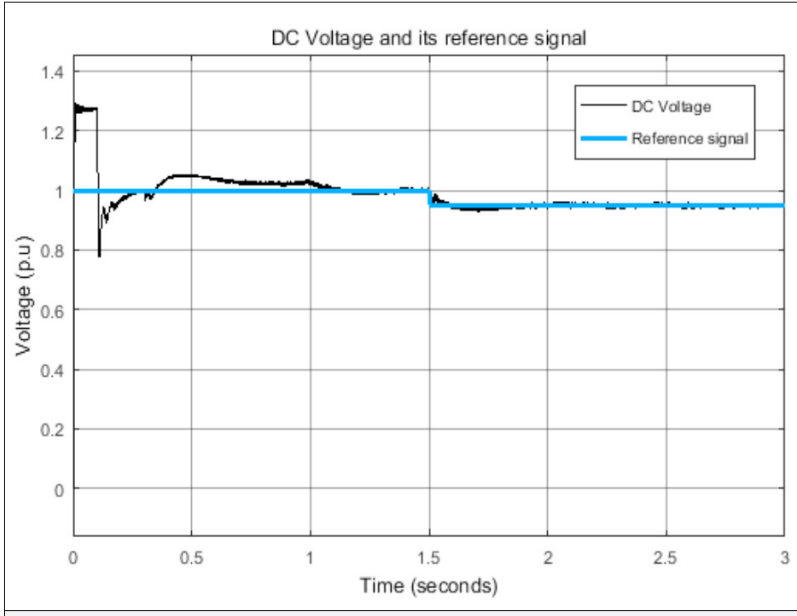

Figure 12. Response to step change of DC voltage at onshore bus station

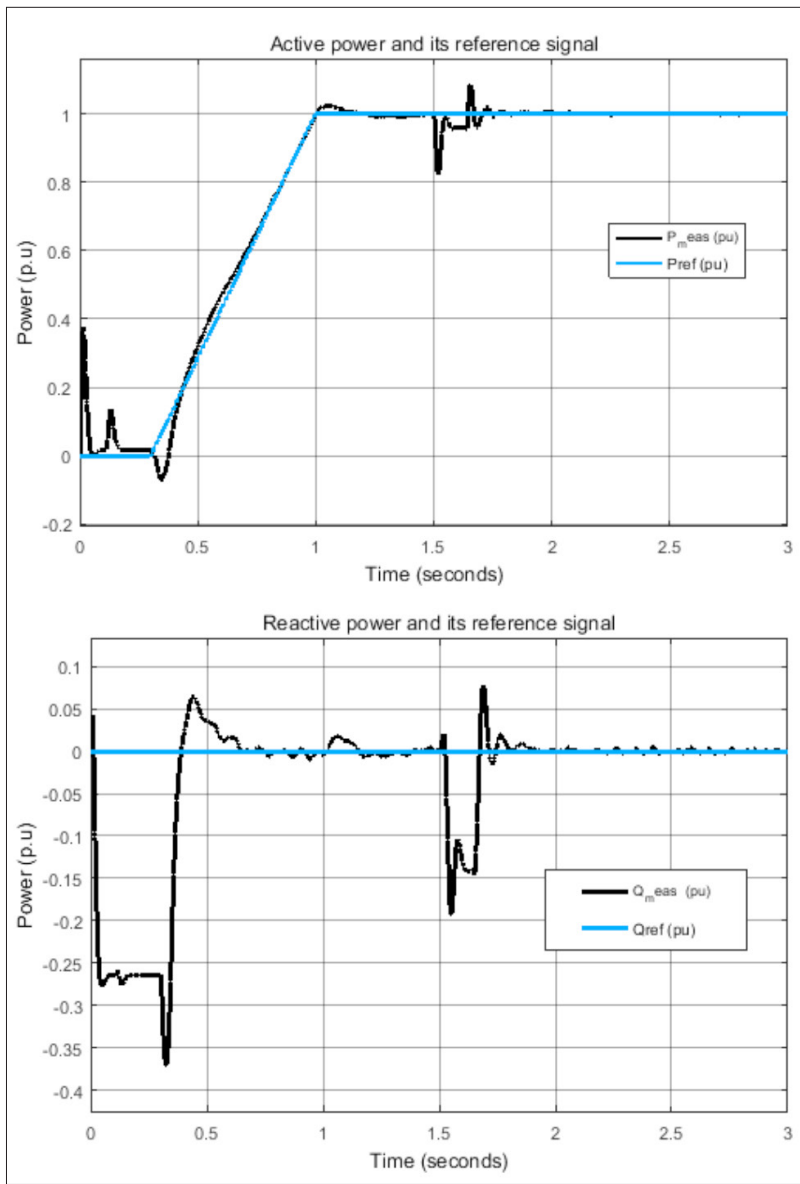

Figure 13. Voltage sag at offshore converter Station

The power generated from the offshore wind farm delivered the required amount of energy to the grid through HVDC transmission, which is converted to three-phase $A C$ and ready consumption. In this work, a simple AC system of 230 $\mathrm{KV}$ is modeled that operates at $50 \mathrm{~Hz}$ frequency. It is observed



Figure 14. Response to the fault at the HVDC side



(a)



(b)

Figure 15. a, b. Response to fault at offshore wind farm to (a) active power $(b)$ reactive power

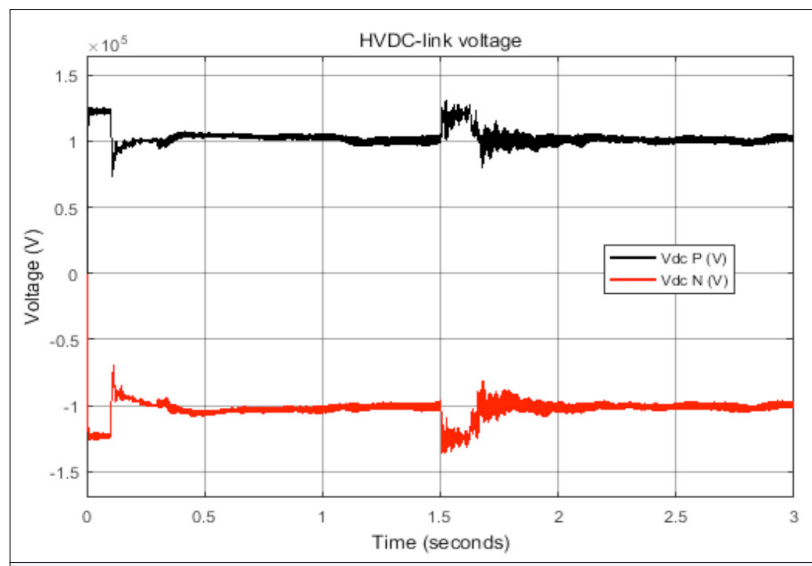

Figure 16. HVDC-link voltage at onshore under fault condition

that the voltage at offshore converter bus is 1.0p.u (230 KV), which is sufficient to supply energy to consumer terminal voltage. 


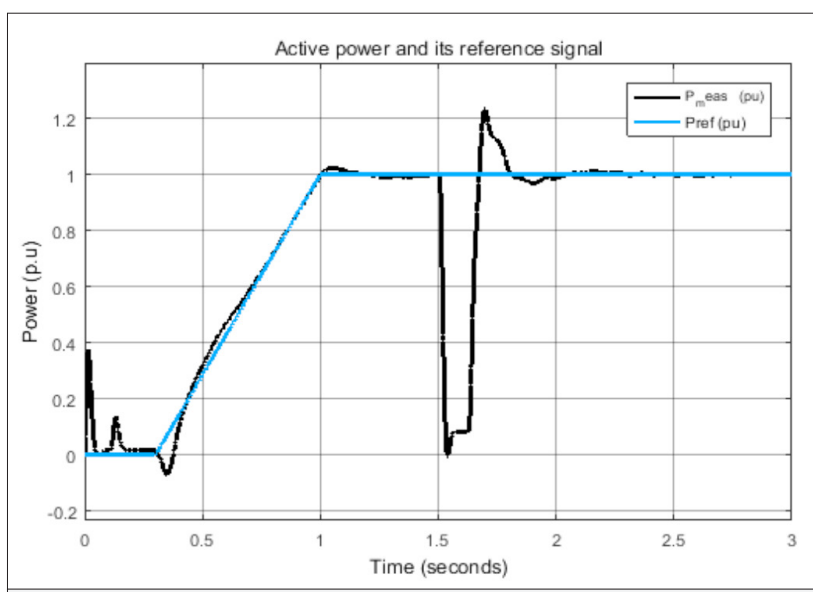

Figure 17. Three-phase to ground fault at onshore converter station



\section{Conclusions}

In this paper, design and control of an offshore wind farm connected through HVDC transmission is implemented. The offshore wind farm is designed to deliver power to an AC main grid using HVDC by an undersea cable transmission. Unlike the conventional thyristor based converters that use thyristor valves, a VSC employing IGBT switches with SVPWM techniques are used. A DFIG is used for driving the wind turbines due to its variable speed operation. The transmission of power is achieved by the use of converter (rectifier station) at offshore side for converting the AC voltage supplied by wind turbine generators into DC and then transmitted through undersea cables. This transmitted power is then converted back (inverter station) to AC to feed the grid. The control of this system is achieved through the control of wind turbine generators and wind speed by ensuring that high quality power is delivered to the grid.

The developed control strategy verified the dynamic and transient operation of the system to VSC-based-HVDC transmission. It involved control of active and reactive power at the offshore side and maintaining DC voltage and reactive power at the onshore side. It has been verified that active and reactive power can be controlled independently from one another and by increasing and decreasing step changes to their reference value. Also variation in wind speed can have an effect on the dynamic performance of the system. In addition, the performance of the controllers is analyzed during fault and it is verified that threephase fault could be very critical with regard to the the system when compared to an unbalance fault.

Peer-review: Externally peer-reviewed.

Conflict of Interest: The authors have no conflicts of interest to declare.

Financial Disclosure: The authors declared that this study has received no financial support.

\section{References}

1. J. Lin, "Integrating the First HVDC-Based Offshore Wind Power into PJM System - A Real Project Case Study", PJM Interconnection, Audubon, PA 19403, USA, pp. 1-8, 2015.

2. L. Wang, K.-H. Wang, W.-J. Lee, Z. Chen "Power-flow control and stability enhancement of four parallel-operated offshore wind farms using a line-commutated HVDC link", IEEE Transactions on Power Delivery, vol. 25, no. 2, pp. 1190-1202, 2010.

3. F. Careri, S. Member, C. Genesi, P. Marannino, "Centralized coordinated control of VSC-HVDC link and DFIGs in very large offshore wind power plants", IEEE Trondheim PowerTech, pp. 1-8, 2011.

4. J. Lin, "Integrating the First HVDC-Based Offshore Wind Power into PJM System - A Real Project Case Study", IEEE Industry Applications Society Annual Meeting, pp. 1-8, 2015.

5. D. Elliott, K. R. W. Bell, S. J. Finney, R. Adapa, C. Bronzio, J. Yu, K. Hussain, "A Comparison of AC and HVDC Options for the Connection of Offshore Wind Generation in Great Britain", IEEE Transactions on Power Delivery, vol. 31, no. 2, pp. 798-809, 2016.

6. X. Rong, D. E. Macpherson,J. K. H. Shek, "The Effect of High Power DC-DC Converter in Offshore Multi-Terminal Medium and High Voltage DC Networks", International Conference on Renewable Power Generation (RPG 2015), 2015.

7. G. Asplund, K. Eriksson, H. Jiang, J. Lindberg, R. Pålsson, K. Svensson, "DC Transmission Based on Voltage Source Converters," $A B B$ Power Syst AB, pp.1-10, 1997.

8. G. Asplund, "Sustainable energy systems with HVDC transmission," pp. 1-5, 1999.

9. D. Stanley, "The Directlink VSC-Based HVDC Project and its Commissioning", Cigre, vol. 14, no.108, pp. 9-18, 2002.

10. H. Light, "The world's most remote offshore wind farm BorWin1 HVDC Light ${ }^{\circledR}$ offshore wind farm link", 2011.

11. Z. Chen, Y. Hu, F. Blaabjerg, "Stability improvement of induction generator-based wind turbine systems,"IET Renew Power Gener, vol. 1, no.1, pp. 81-93, 2007.

12. S. Lauria, M. Schembari, F. Palone, M. Maccioni, "Very long distance connection of gigawatt- size offshore wind farms : extra high-voltage AC versus high-voltage DC cost comparison", IET Renewable Power Generation, vol. 1, pp. 713-720, 2015.

13. Y. Keche, V. K. Chandrakar, "Integrated operation of Grid and HVDC connected Offshore Wind Farm", International Conference on Computation of Power, Energy Information and Communication (ICCPEIC), pp. 666-674, 2016. 
14. R. Safaeian, S. Ebrahimi, M. Parniani, "Performance Improvement of Steady-State and Transient Operation of Offshore Wind Farm HVDC Power Transmission", IEEE $16^{\text {th }}$ Workshop on Control and Modeling for Power Electronics (COMPEL), 2015.

15. S. Muller, M. Diecke, W. Rik, "Doubly fed induction Generator systems for wind turbine," IEEE Industry Application, vol. 2, no. 1, pp. 26-33, 2002.

16. J. B. Ekanayake, L. Holdsworth, N. Jenkins, “Comparison of $5^{\text {th }}$ order and $3^{\text {rd }}$ order machine models for doubly fed induction generator wind turbines," Electr Power Syst Res, vol. 67, pp. 207-215, 2003.

17. S. Bozhko, G. Asher, R. Li, J. Clare, S. Member, L. Yao, "Large Offshore DFIG-Based Wind Farm With Line-Commutated HVDC Connection to the Main Grid : Engineering Studies", IEEE Trans Energy Convers, vol. 23, no. 1, pp. 119-127, 2008.

18. P. Bresesti, W. L. Kling, R. L. Hendriks, R. Vailati, "HVDC Connection of Offshore Wind Farms to the Transmission System", IEEE Trans Energy Convers, vol. 22, no. 1, pp. 37-43, 2007.

19. R. Iravani, A. Yazdani, "Voltage-Sourced Converters in Power Systems:Modeling, Control, and Applications", New York, NY: Wiley-IEEE Press, 2010.

20. N. Flourentzou, S. Member, V. G. Agelidis, S. Member, G. D. Demetriades, "VSC-Based HVDC Power Transmission Systems : An Overview", IEEE Transtactions Power Electron, vol. 24, no. 3, pp. 592-602, 2009. [21] A. Irina Stan, D. Ioan Stroe "Control of VSC-Based HVDC Transmission System for Offshore Wind," Master Thesis, Aalborg university Denmark, 2010.

22. F. Deng, Z. Chen, "An Offshore Wind Farm with DC Grid Connection and Its Performance under Power System Transients", IEEE Power and Energy Society General Meeting, 2011.

23. M. Zhao. Z. Chen. F. Blaabjerg, "Optimisation of electrical system for offshore wind farms via genetic algorithm," IET Renew. Power Gener, vol. 3, no.2, pp. 205-216, 2009.
24. J. Bhukya, V. Mahajan, "The controlling of the DFIG based on variable speed wind turbine modeling and simulation", IEEE 6th International Conference on Power Systems (ICPS), 2016.

25. Y. Li, Z. Xu, J. Ostergaard, D. J. Hill, "Coordinated Control Strategies for Offshore Wind Farm Integration via VSC - HVDC for System Frequency Support", IEEE Trans. Energy Convers, vol. 32, no. 3, pp. 843856, 2017.

26. S. Dinesh, R. Meenakshi, M. S. Suhanya, M. S. Kumaran, R. Muthu, "Modeling and Direct Power Control of DFIG for Wind Energy Conversion System with a Back to Back Converter", International Conference on Green Computing Communication and Electrical Engineering (ICGCCEE), 2014.

27. L. Xu, S. Member, L. Yao, and C. Sasse, "Grid Integration of Large DFIG-Based Wind Farms Using VSC Transmission," IEEE Trans Power Syst, vol. 22, no. 3, pp. 976-984, 2007.

28. M. M. Z. Moustafa, O. Nzimako, A. Dekhordi, "Modelling of Wind Energy Sources in Real Time Platform", $28^{\text {th }}$ International Conference on Microelectronics (ICM), 2016.

29 T. M. Haileselassie, "Control of Multi-terminal VSC-HVDC Systems", Master Thesis, Norwegian Univ of Tech., 2008.

30. K. Karthi, R. Radhakrishnan, J. M. Baskaran, L. S. Titus, “Performance Analysis on Various Controllers of VSC - HVDC Transmission Systems", IEEE International Conference on Computational Intelligence and Computing Research, 2016.

31. C. Zhao, C. Guo, "Complete-Independent Control Strategy of Active and Reactive Power for VSC Based HVDC System", IEEE Power \& Energy Society General Meeting, 2009.

32. Ch.Yaswanth, A.Vijayasri "VSC Based HVDC Sytem Design and Protection against Over Voltages", International Journal of Engineering Research and Development, vol. 10, no. 12, pp. 46-57, 2014.
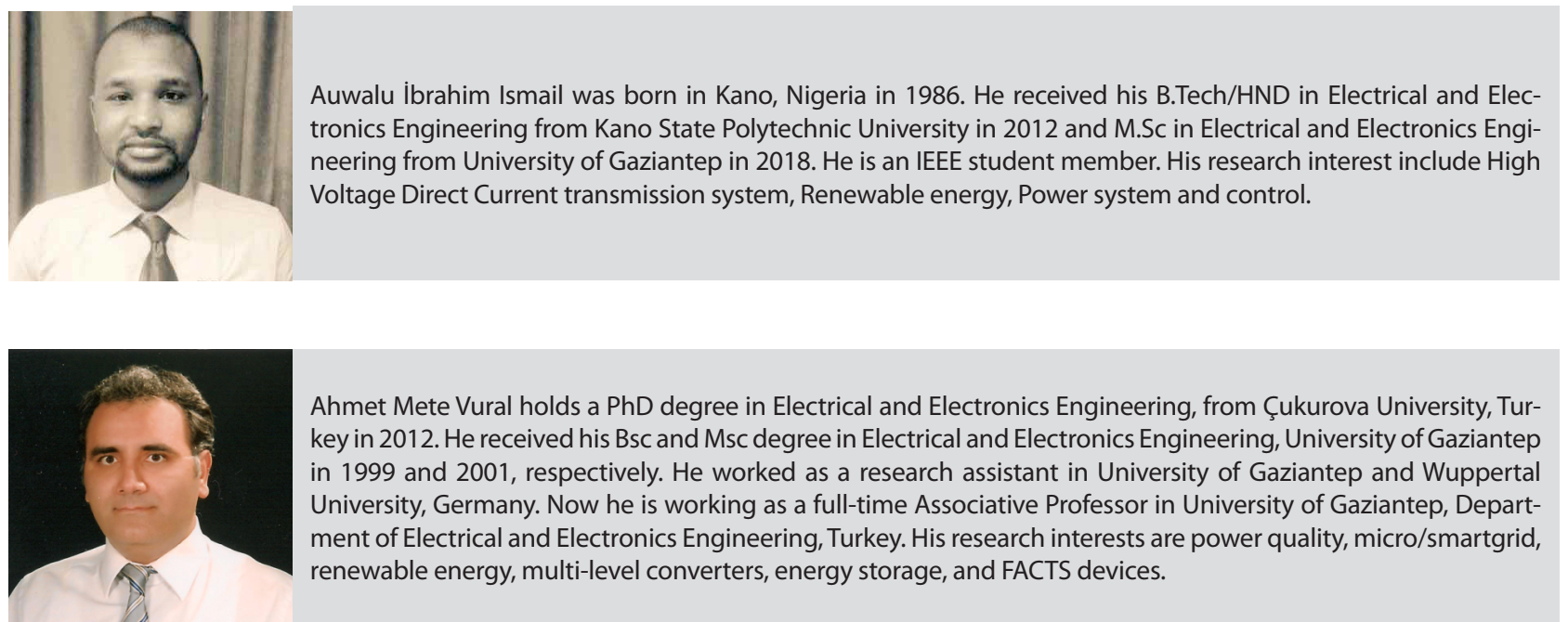

Ahmet Mete Vural holds a PhD degree in Electrical and Electronics Engineering, from Çukurova University, Turkey in 2012. He received his Bsc and Msc degree in Electrical and Electronics Engineering, University of Gaziantep in 1999 and 2001, respectively. He worked as a research assistant in University of Gaziantep and Wuppertal University, Germany. Now he is working as a full-time Associative Professor in University of Gaziantep, Department of Electrical and Electronics Engineering, Turkey. His research interests are power quality, micro/smartgrid, renewable energy, multi-level converters, energy storage, and FACTS devices. 